\title{
Classification of Polarimetric SAR Data Using Dictionary Learning
}

\author{
Vestergaard, Jacob Schack; Nielsen, Allan Aasbjerg; Dahl, Anders Lindbjerg; Larsen, Rasmus
}

Published in:

Proceedings of SPIE - The International Society for Optical Engineering

Link to article, DOI:

$10.1117 / 12.974814$

Publication date:

2012

Document Version

Publisher's PDF, also known as Version of record

Link back to DTU Orbit

Citation $(A P A)$ :

Vestergaard, J. S., Nielsen, A. A., Dahl, A. L., \& Larsen, R. (2012). Classification of Polarimetric SAR Data Using Dictionary Learning. Proceedings of SPIE - The International Society for Optical Engineering, 8537, 85370X . https://doi.org/10.1117/12.974814

\section{General rights}

Copyright and moral rights for the publications made accessible in the public portal are retained by the authors and/or other copyright owners and it is a condition of accessing publications that users recognise and abide by the legal requirements associated with these rights.

- Users may download and print one copy of any publication from the public portal for the purpose of private study or research.

- You may not further distribute the material or use it for any profit-making activity or commercial gain

- You may freely distribute the URL identifying the publication in the public portal 


\title{
Classification of Polarimetric SAR Data Using Dictionary Learning
}

\author{
Jacob S. Vestergaard ${ }^{a}$, Allan A. Nielsen $^{b}$, Anders L. Dahl $^{a}$ and Rasmus Larsen ${ }^{a}$ \\ ${ }^{a}$ Technical University of Denmark \\ DTU Informatics - Informatics and Mathematical Modelling \\ DK-2800 Kgs. Lyngby, Denmark \\ ${ }^{b}$ Technical University of Denmark \\ DTU Space - National Space Institute \\ DK-2800 Kgs. Lyngby, Denmark
}

\begin{abstract}
This contribution deals with classification of multilook fully polarimetric synthetic aperture radar (SAR) data by learning a dictionary of crop types present in the Foulum test site. The Foulum test site contains a large number of agricultural fields, as well as lakes, forests, natural vegetation, grasslands and urban areas, which make it ideally suited for evaluation of classification algorithms.

Dictionary learning centers around building a collection of image patches typical for the classification problem at hand. This requires initial manual labeling of the classes present in the data and is thus a method for supervised classification. Sparse coding of these image patches aims to maintain a proficient number of typical patches and associated labels. Data is consecutively classified by a nearest neighbor search of the dictionary elements and labeled with probabilities of each class.

Each dictionary element consists of one or more features, such as spectral measurements, in a neighborhood around each pixel. For polarimetric SAR data these features are the elements of the complex covariance matrix for each pixel. We quantitatively compare the effect of using different representations of the covariance matrix as the dictionary element features. Furthermore, we compare the method of dictionary learning, in the context of classifying polarimetric SAR data, with standard classification methods based on single-pixel measurements.
\end{abstract}

Keywords: Polarimetric SAR, dictionary learning, Foulum, classification

Further author information:

J.S.V.: Located at DTU Informatics - Informatics and Mathematical Modelling, Asmussens Allé, Building 321, E-mail jsve@imm.dtu.dk, http://www.imm.dtu.dk/ jsve, Tel +45 4525 3425, Fax +45 45881397.

A.A.: E-mail aa@space.dtu.dk, http://www.imm.dtu.dk/ aa.

A.L.D.: E-mail abd@imm.dtu.dk, http://www.imm.dtu.dk/ abd.

R.L.: E-mail rl@imm.dtu.dk, http://www.imm.dtu.dk/ rl. 